\title{
Response of Different Bread Wheat (Triticum aestivum L.) Genotypes to Post-Anthesis Water Deficit
}

\author{
Hamdollah ESKANDARI'), Kamyar KAZEMI') \\ 1) University of Payame Noor, Omidieh Branch, Department of Agriculture,Omidieh, Iran; ehamdollah@gmail.com \\ 2) University of Payame Noor, Shadegan Branch, Department of Agriculture, Shadegan, Iran
}

\begin{abstract}
Resources of water are limited in many agricultural areas of West Asia. Therefore, effective use of this scarce resource is very important in this region. So, this research was conducted in 2009-2010 growing season at Research Farm of Agricultural Researches Center of Khuzestan, Iran, to investigate the effects of two irrigation regime $\left(\mathrm{I}_{1}\right.$ : normal irrigation and $\mathrm{I}_{2}$ : no irrigation in post-anthesis growth stage) on grain yield of five wheat cultivars ('Chamran,' 'S-78-11', 'A', 'S-80-18' and 'S-82-10'). A split plot experiment based on randomized complete block design in three replications was used, with the irrigation regime in main plots and wheat cultivars in subplots. The results showed that 1000-grain weight, grains per spikelet and grain yield were decreased by water limitation. Despite of their significant differences $(\mathrm{P}<0.05)$ in 1000-grain weight, spikelets per spike and grains per spike, the grain yield of wheat cultivars was not significantly different. It was resulted by different grain yield reduction of genotypes under different irrigation regimes. Genotypes 'S-80-18' and 'S-7811' produced highest yield under normal irrigation and drought stress conditions, respectively. The yield reduction of 'S-80-18' genotype was highest under drought stress conditions. 'S-78-11' was the most tolerant genotype to water deficit occurrence.
\end{abstract}

Keywords: agronomic traits, drought stress, wheat grain yield, yield components

\section{Introduction}

Water limitation, especially after anthesis, is a major abiotic stress which severely affects wheat production in most part of central Asia and the Middle-East including Iran. Therefore, selection and breeding for drought tolerance has been the main challenge of wheat breeders and wheat scientists throughout the last 50 years (Lopes et al., 2003).

Wheat is an important crop in southwest Iran, especially, Khuzestan, where low precipitation and high temperature occur during grain filling period of wheat growth in April and May (Modhej, 2006). Therefore, yield is lowered. The ability of a cultivar to produce high yield over a wide range of environmental condition is very important (Rashid et al., 2003). The response of plants to water stress depends on several factors such as developmental stage, severity and duration of stress and cultivar genetics (Beltrano and Marta, 2008). Drought stress may occur throughout the growing season, early or late season, but its effect on yield reduction is high when it occurs after anthesis (Nouri-Ganbalani et al., 2009). Drought stress after anthesis usually result in smaller grain size (Jamieson et al., 1995) both from direct effects on the grain and also because of accelerated flag leaf senescence (Hafsi et al., 2000)

Morphological characters such as root length, spike number per $\mathrm{m}^{2}$, grain number per spike, 1000-gain weight, awn length (Moustafa et al., 1996; Boyer, 1996; Plaut et al.,
2004; Blum, 2005), physiological traits such as rate of root respiration (Liu et al., 2004) and phonological characters such as number of days to heading, anthesis and maturity (Austin, 1987) affect wheat tolerance to the moisture shortage in the soil. Under different drought treatment, Guinata et al. (1993) suggested that grain number per spike and spikes per unit area were the wheat yield components most sensitive to drought stress. Other studies have indicated that variation in grain yield between moisture regimes was predominantly associated with variation in spikes per unit area and grains per spike (Simane et al., 1993).

In Iran, water shortage is very common in late season after the anthesis, even in irrigated lands. Therefore, the availability of wheat cultivars tolerant to the water deficit in the late season is essential to the sustainable production of this important crop. Thus, the present study was aimed screening out drought tolerant varieties of wheat, which can adapt to the drought conditions in Iran, particularly in the southwest region.

\section{Materials and methods}

The experiment was conducted at research Farm of Agricultural Researches Center of Khuzestan, Iran (latitude $32^{\circ} 20^{\prime} \mathrm{N}$, longitude $48^{\circ} 20^{\prime} \mathrm{E}$, altitude $50 \mathrm{~m}$ above sea level) in 2009-2010 growing season. The climate is characterized by mean annual precipitation of $240 \mathrm{~mm}$, mean annual temperature of $25^{\circ} \mathrm{C}$, annual maximum tempera- 
50

ture of $51.2^{\circ} \mathrm{C}$ and mean annual minimum temperature of $-1^{\circ} \mathrm{C}$. Soil type was clay-loam with $\mathrm{EC}$ of $2.8 \mathrm{dsm}^{-1}$ and $\mathrm{pH}$ of 7.6.

Seeds were hand sown in $4 \mathrm{~cm}$ depth with density of $400 \mathrm{~m}^{-2}$ on 6 November 2009. Each plot consisted of 6 rows with $2.5 \mathrm{~m}$ length, spaced $30 \mathrm{~cm}$ apart. Experimental design was split plot, based on RCB design with three replications. The main plots were allocated to irrigation regimes $\left(\mathrm{I}_{1}\right.$ : normal irrigation, where the plots were irrigated 6 times with an approximately 10 days intervals throughout the growing season, started at the end of rainfall season in Mach; and $\mathrm{I}_{2}$ : no irrigation in post-anthesis growth stage), while the sub-plots were assigned for wheat cultivars ('Chmaran', 'S-78-11', 'A', 'S-80-18' and 'S-82-10'). All plots were fertilized with the same amount of fertilizer. The fertilizers containing $\mathrm{N} \mathrm{50,} \mathrm{P}_{2} \mathrm{O}_{5} 90$ and $\mathrm{K}_{2} \mathrm{O} 50 \mathrm{~kg}$ $\mathrm{ha}^{-1}$ were broadcast before sowing. An additional $50 \mathrm{~kg}$ of $\mathrm{N} \mathrm{ha}^{-1}$ were applied at two growth stages of after tillering and the beginning of flowering. Weeds were chemically controlled, using Topik (1lit ha $\left.\mathrm{a}^{-1}\right)$ and Granstar $\left(15 \mathrm{~g} \mathrm{ha}^{-1}\right)$ herbicides.

At maturity, all plants of $6 \mathrm{~m}^{2}$ area of each plot were harvested and then, grains per spikelets, spikelets per spike, grains per spike, spikes per unit area, 1000-grains weight and grain yield per unit area for each treatment at each replicate were determined.

Analysis of variance was carried out with MSTATC and the results were used to evaluate the effect of drought stress, wheat genotype and the drought $\times$ genotype effects. The means were compared by Duncan's multiple range method at 0.05 probability level, using MSTATC software program.

\section{Results and discussions}

Grains per spike and 1000-grains weight were significantly $(\mathrm{P}=0.05)$ affected by irrigation regimes and cultivars (Tab. 1). The effect of irrigation on grain yield was also significant $(\mathrm{P}=0.01)$, but cultivar had not significant effect on this trait (Tab. 1). Spikes per unit area and spikelets per spikes were not significantly affected by water supply, but the effect of cultivars on these traits was significant (Tab. 1).

Generally, the number of grains per spike, 1000-grain weight and grain yield per unit area decreased with deceasing water availability (Tab. 3). Mean spikelets per spike and grains per spike of 'Chamran' cultivar were significantly $(\mathrm{P}<0.05)$ lower than that of the other wheat cultivars, but it produced the highest spikes per unit area (Tab. 2). The largest grains were produced by 'S-82-10', followed by 'A' cultivar (Tab. 2).

The interaction of irrigation $\times$ cultivar for 1000-grains weight, grain yield, spikelets per spike and grains per spike was significant $(\mathrm{P}=0.05)$ (Tab. 1). Even though the highest grain yield was observed under normal irrigation regime $\left(\mathrm{I}_{1}\right)$ for 'S-80-18' cultivar. However, 'S-80-18' cultivar had
Tab. 1. Interactive effect of treatments, grain yields $\left(\mathrm{kg} \mathrm{ha}^{-1}\right)$ and yield components

\begin{tabular}{|c|c|c|c|c|c|c|c|}
\hline $\begin{array}{l}\text { Source of } \\
\text { variance }\end{array}$ & Df & $\begin{array}{l}\text { Grain } \\
\text { yield }\end{array}$ & $\begin{array}{l}\text { Spike } \\
\text { per } \\
\text { unit } \\
\text { area } \\
\end{array}$ & $\begin{array}{c}\text { Spikelet } \\
\text { per } \\
\text { spike }\end{array}$ & $\begin{array}{l}\text { Grain } \\
\text { per } \\
\text { spike }\end{array}$ & $\begin{array}{c}\text { Grain } \\
\text { per } \\
\text { spikelets }\end{array}$ & $\begin{array}{l}\text { 1000- } \\
\text { grains } \\
\text { weight }\end{array}$ \\
\hline Replication & 2 & $358579^{\circ}$ & 47626 & $1.9^{\circ}$ & $12.2^{\mathrm{ns}}$ & $0.006^{\mathrm{ns}}$ & $6.7^{\circ}$ \\
\hline Irrigation & 1 & $5012706^{\circ}$ & $2521^{\mathrm{ns}}$ & $2.1^{\mathrm{ns}}$ & $90.1^{\circ}$ & $0.065^{\text {ns }}$ & $30.0^{* *}$ \\
\hline Error & 2 & 937924 & 2286 & 1.2 & 58.6 & 0.15 & 6.3 \\
\hline Cultivar & 4 & $100815^{\mathrm{ns}}$ & $37839^{\circ}$ & $6.8^{\prime \prime}$ & $97.8^{* *}$ & $0.075^{\text {ns }}$ & $54.5^{\prime \prime}$ \\
\hline $\begin{array}{l}\text { Irrigation } \\
\times \text { cultivar }\end{array}$ & 4 & $696863^{\circ}$ & $6623^{\text {ns }}$ & $2.7^{*}$ & $33.0^{*}$ & $0.025^{\mathrm{ns}}$ & $1.7^{\circ}$ \\
\hline Error 2 & 16 & 336418 & 22833 & 1.1 & 32.3 & 0.062 & 4.7 \\
\hline
\end{tabular}

Tab. 2. Grain yield $\left(\mathrm{kg} \mathrm{ha}^{-1}\right)$ and yield components of different wheat cultivars

\begin{tabular}{cccccc}
\hline Cultivar & $\begin{array}{c}\text { Spike per } \\
\text { unit area }\end{array}$ & $\begin{array}{c}\text { Spikelet } \\
\text { per spike }\end{array}$ & $\begin{array}{c}\text { Grain } \\
\text { per spike }\end{array}$ & $\begin{array}{c}\text { Grain per } \\
\text { spikelets }\end{array}$ & $\begin{array}{c}1000 \text {-grains } \\
\text { weight }\end{array}$ \\
\hline 'Chamran' & $615 \mathrm{a}$ & $13 \mathrm{~b}$ & $37 \mathrm{~b}$ & $2.6 \mathrm{a}$ & $41.0 \mathrm{bc}$ \\
'S-78-11' & $432 \mathrm{~b}$ & $16 \mathrm{a}$ & $44 \mathrm{ab}$ & $2.7 \mathrm{a}$ & $36.6 \mathrm{~d}$ \\
'A' & $494 \mathrm{ab}$ & $16 \mathrm{a}$ & $46 \mathrm{a}$ & $2.8 \mathrm{a}$ & $43.0 \mathrm{ab}$ \\
\hline 'S-80-18' & $525 \mathrm{ab}$ & $15 \mathrm{a}$ & $39 \mathrm{ab}$ & $2.5 \mathrm{a}$ & $39.8 \mathrm{c}$ \\
'S-82-10' & $418 \mathrm{~b}$ & $16 \mathrm{a}$ & $45 \mathrm{a}$ & $2.7 \mathrm{a}$ & $44.5 \mathrm{a}$ \\
\hline
\end{tabular}

Different letters in each column indicates significant difference at $5 \%$ level of probability according to value of LSD

the lowest grain yield under water deficit condition, indicating that ' $\mathrm{S}-80-18$ ', with $31 \%$ grain yield reduction, is the most sensitive cultivar to post-anthesis water shortage (Tab. 3). Bahrani et al. (2009) reported that post-anthesis water deficit stress resulted in wheat grain yield reduction. Moussavi-Nik et al. (2007) working on wheat, obtained similar results where grain yield of wheat was decreased by no irrigation after pollination treatment. 'S-78-11' cultivar had the highest number of spikelets per spike and grains per spike under normal irrigation regime, but it had the lowest 1000-grains weight under two irrigation regimes. 'S-78-11' cultivar, with $4 \%$ grain yield reduction, had the highest resistance to post-anthesis drought stress (Tab. 3).

The grain yield of any genotype is influenced by a complex of different morphological, physiological and phonological traits of that genotype which are in turn influenced by soil moisture. Since the environmental conditions vary in different areas, the response of plant traits to drought stress and expected grain yield also varies in different locations. Normal irrigation compared to drought stress increased the grains number per spike, 1000-grains weight and grain yield (Tab. 3). Therefore, it could be concluded that if irrigation water is available, the crop must be irrigated, particularly after anthesis to obtain higher grain yield as was similarly reported by Saxena and Saxena (1990) that the irrigation of wheat crop at drought development stage of grains has increased the grain yield as much as $1340 \mathrm{~kg}$ $\mathrm{ha}^{-1}$. Also, Saxena et al. (1989) found that $13 \mathrm{~mm}$ irrigation of the crop at anthesis stage has increased the grain 
Tab. 3. Mean yield and yield components of wheat cultivars under different irrigation treatments

\begin{tabular}{cccccccc}
\hline $\begin{array}{c}\text { Irrigation } \\
\text { regime }\end{array}$ & Cultivar & $\begin{array}{c}\text { Grain yield } \\
\left(\mathrm{kg} \mathrm{ha}^{-1}\right)\end{array}$ & $\begin{array}{c}\text { Spike per } \\
\text { unit area }\end{array}$ & Spikelet per spike & $\begin{array}{c}\text { Grain per } \\
\text { spike }\end{array}$ & $\begin{array}{c}\text { Grain per } \\
\text { spikelets }\end{array}$ & $\begin{array}{c}\text { 1000-grains } \\
\text { weight }\end{array}$ \\
\hline $\mathrm{I}_{1}$ & 'Chamran' & $5666 \mathrm{ab}$ & $603.3 \mathrm{a}$ & $13.3 \mathrm{c}$ & $39.6 \mathrm{ab}$ & $2.6 \mathrm{a}$ & $41.6 \mathrm{bc}$ \\
& 'S-78-11' & $4958 \mathrm{abc}$ & $411.6 \mathrm{a}$ & $17.0 \mathrm{a}$ & $41.6 \mathrm{ab}$ & $2.8 \mathrm{a}$ & $38.3 \mathrm{~cd}$ \\
& 'A' & $5720 \mathrm{ab}$ & $521.6 \mathrm{a}$ & $16.0 \mathrm{ab}$ & $48.0 \mathrm{a}$ & $2.9 \mathrm{a}$ & $43.6 \mathrm{ab}$ \\
& 'S-80-18' & $6086 \mathrm{a}$ & $541.6 \mathrm{a}$ & $16.3 \mathrm{ab}$ & $49.0 \mathrm{a}$ & $2.5 \mathrm{a}$ & $40.3 \mathrm{bc}$ \\
& 'S-82-10' & $5430 \mathrm{abc}$ & $410.0 \mathrm{a}$ & $16.6 \mathrm{a}$ & $48.0 \mathrm{a}$ & $2.8 \mathrm{a}$ & $46.0 \mathrm{a}$ \\
\hline $\mathrm{I}_{2}$ & Mean & $5572 \mathrm{a}$ & $497.0 \mathrm{a}$ & $15.8 \mathrm{a}$ & $44.0 \mathrm{a}$ & $2.7 \mathrm{a}$ & $42.0 \mathrm{a}$ \\
\hline & 'Chamran' & $4722 \mathrm{bc}$ & $628.3 \mathrm{a}$ & $14.3 \mathrm{c}$ & $35.0 \mathrm{~b}$ & $2.7 \mathrm{a}$ & $39.3 \mathrm{bc}$ \\
& 'S-78-11' & $4906 \mathrm{abc}$ & $420.0 \mathrm{a}$ & $15.0 \mathrm{~b}$ & $36.6 \mathrm{~b}$ & $2.6 \mathrm{a}$ & $35.0 \mathrm{~cd}$ \\
& 'A' & $4833 \mathrm{bc}$ & $500.0 \mathrm{a}$ & $16.6 \mathrm{a}$ & $45.3 \mathrm{ab}$ & $2.7 \mathrm{a}$ & $41.3 \mathrm{abc}$ \\
\hline & 'S-80-18' & $4278 \mathrm{c}$ & $508.3 \mathrm{a}$ & $14.3 \mathrm{c}$ & $40.3 \mathrm{ab}$ & $2.5 \mathrm{a}$ & $38.3 \mathrm{bc}$ \\
\hline
\end{tabular}

Different letters in each column indicates significant difference at $5 \%$ level of probability according to value of LSD

yield $583 \mathrm{~kg} \mathrm{ha}^{-1}$. Ehdaie and Waines (1989) concluded that irrigation of wheat crop after anthesis increased the grain yield to $813 \mathrm{~kg} \mathrm{ha}^{-1}$.

the two yield related traits reduced significantly by water deficit. There was a positive significant correlation between 1000-grains weight and grain yield $(\mathrm{r}=0.61, \mathrm{P} \leq$ 0.05) (Tab. 4). Other researchers such as Passioura (1977), Khan and Ashraf (1993) have also reported a positive correlation between the grain yield and 1000-grains weight. Machado et al. (1993) concluded that drought stress reduced the allocation of photosynthetic material to the grains and, thus, caused significant reduction in 1000grains weight. Royo et al. (1999) reported that water deficit and high temperature in late season reduced grain filling period and, thus, grain weight. Royo et al. (2000), also out found that drought stress in grain formation and filling period reduced grain weight of triticale.

Increased number of grains per spike is an important yield component that influences the grain yield (Calderini et al., 1999). In this experiment, water deficit reduced grains per spike (Tab. 3). Positive correlation between grain yield and grain nymber per spike (Tab. 4) shows that

Tab. 4. Correlation coefficient between grain yield and yield components of wheat genotypes

\begin{tabular}{cccccc}
\hline & $\begin{array}{c}\text { Grain } \\
\text { yield }\end{array}$ & $\begin{array}{c}\text { Spike per } \\
\text { unit area }\end{array}$ & $\begin{array}{c}\text { Spikelets } \\
\text { per spike }\end{array}$ & $\begin{array}{c}\text { Grain } \\
\text { per spike }\end{array}$ & $\begin{array}{c}\text { 1000-grains } \\
\text { weight }\end{array}$ \\
\hline $\begin{array}{c}\text { Grain } \\
\text { yield }\end{array}$ & 1 & & & & \\
$\begin{array}{c}\text { Spike per } \\
\text { unit area }\end{array}$ & 0.06 & 1 & & & \\
$\begin{array}{c}\text { Spikelets } \\
\text { per spike }\end{array}$ & 0.32 & -0.20 & 1 & & \\
$\begin{array}{c}\text { Grain per } \\
\text { spike }\end{array}$ & 0.66 & 0.24 & $0.70^{*}$ & 1 & \\
$\begin{array}{c}1000 \text {-grain } \\
\text { weight }\end{array}$ & $0.61^{\circ}$ & 0.20 & -0.11 & -0.07 & 1 \\
\hline
\end{tabular}

indicates significance at 0.05 probability level sufficient irrigation results in higher grain yield by increasing grain number per spike. Similar results have been reported by other researchers. Elhafid et al. (1998) demonstrated that drought stress results in reduced pollination and reduced the number of grains per spike. Fisher (1985) and Nouri-Ganbalani et al. (2009) also obtained similar results in their studies. Mirbahar et al. (2009) reported the significant suppressive effect of post-flowering drought on number of grains per spike in wheat.

\section{Conclusions}

Genotype 'S-80-18' and 'S-78-11' produced highest yield under normal irrigation and drought stress conditions, respectively. The yield reduction of 'S-80-18' genotype was highest under drought stress conditions. 'S-78-11' was the most tolerant genotype to water deficit occurrence. Kindly describe what characteristics or attributes of 'S-80-18' could make it that tolerant.

\section{References}

Austin, R. B. (1987). Some crop characteristics of wheat and their influence on yield and water use, pp. 321-336. In: Srivatava J. P., J. P. Porceddu, E., Acevedo and S. Varma. (Eds.). Drought Tolerance in Winter Cereals. John Wiley and Sons, New York.

Bahrani, A., H. Heidari-Sharifabad, Z. Tahmasebi-Sarvestani, G. H. Moafporian and A. Ayenehband (2009). Wheat response to nitrogen and post-anthesis water deficit, pp. 3334. Proceedings of the international conference on CBEE. Singapore.

Beltrano, J. and G. R. Marta (2008). Improved tolerance of wheat plants to drought stress and rewatering by the arbuscular mycorrhizal fungus Glomus claroideum: Effect on growth and cell membrane stability. Braz. J. Plan Physiol. 20(1):112-116 
52

Blum, A. (2005). Mitigation of drought stress by crop management. available at: www. Plant Stress.com. /article/ drought_m/drought_m.htm.mitigation_by_management.

Boyer, J. S. (1996). Advances in drought tolerance in plant. Adv. Agron. 56:187-218.

Calderini, D. F., M. P. Reynolds and G. A. Slafa (1999). Genetic gains in wheat yield and main physiological changes associated with them during the $20^{\text {th }}$ century, pp. 85-93. In: Satorre, E. H. and G. A. (Eds.). Wheat ecology and physiology of yield determination. Food. Products. Press, New York.

Ehdaie, B. and J. G. Waines (1989). Adaptation of land race and improved wheat genotypes to stress environment. J. Genet. Breed. 43:151-156.

Elhafild, R., D. H. Smith, M. Karrou and K. Samir (1998). Morphological attributes associated with early season drought tolerance in spring wheat in a Mediterranean environment. Euphy. 101:273-282.

Fisher, R. A. (1985). Number of kernels in wheat crops and the influence of solar radiation and temperature. J. Agric. Sci. 105:447-461.

Guinata, F. R., R. Motzo, and M. Deidda (1993). Effect of drought on yield and yield components of durum wheat and triticale in Mediterranean environment. Field Cops. Res. 33:399-409.

Hafsi, M., W. Mechenneche., L. Bouamama, A. Djekoune., M. Zahaieva and P. Monneveux (2000). Flag leaf senescence and evaluated by numerical image analysis and its relationship with yield under drought in durum wheat. J. Agron. 185:275-280

Jamieson, P. D., R. J. Martins and G. S. Fancis (1995). Drought influences on grain yield of barley wheat and maize. N. Z. J. Cop Hort. Sci. 23:55-66.

Khan, A. and M. A. Ashraf (1993). Water relation and drought tolerance in two wheat varieties under water stress. Pak. J. Sci. Indust. 36:151-155.

Liu, H. S. and F. M. Li (2004). Deficiemcy of water can enhance root respiration rate of drought-sensitive, but not droughttolerant spring wheat. Agric. Water. Mang. 64:41-48.

Lopez, C. G., G. M. Banowetz, C. J. Peterson and W. E. Kronstad (2003). Dehydrin expression and drought tolerance in seven wheat cultivars. Crop Sci. 43:577-582.

Machado, E. C., A. M. A. Lagoa and M. Ticelli (1993). SourceSink relationship in wheat stress during three productive stage. Revista Brasileria de Fisiologia Vegetal. 5(2):154-150.
Mirbahar, A. A., G. S. Markhand, A. R. Mahar, S. A. Akhter and N. A. Kanhar (2009). Effect of water stress on yield and yield components of wheat varieties. Pak. J. Bot. 41(3):13031310.

Modhej, A. (2006). Effect of heat stress after anthesis on source limitation and grain yield in bread wheat genotypes, pp. 29. Proceeding of the $24^{\text {th }}$ annual meeting of ESCB. Belgium.

Mousssavi-Nik, M., H. R. Mobasser and A. Mehraban (2007). Effect of water stress and potassium chloride on biological and grain yield of different wheat cultivars. Wheat Production in Stressed Environ. 12:655-658.

Moustafa, M. A., L. Boersma and W. E. Kronstad (1996). Response of spring wheat cultivars to drought stress. Crop. Sci. 36:982-986.

Nouri-Ganbalani, A., G. Nouri-Ganbalani and D. Hassan Panah (2009). Effects of drought stress condition on the yield and yielf components of advanced wheat genotypes in Ardabil, Iran. J. Fodd. Agric. Environ. 7(3):228-234.

Passioura, J. B. (1977). Grain yield, harvest index and water use of wheat. J. Aust. Inst. Agric. Sci. 43:117-120.

Plaut, Z., B. J. Butow, C. S. Blumenthal and C. W. Wrigley (2004). Transport of dry matter into developing wheat kernels. Field Crops Res. 96:185-198.

Rashid, A. Q., A. Saleem and H. S. Kazim (2003). Yield potential and stability of nine wheat varieties under water stress conditions. Intr. J. Agric. Bio. 5(1):7-9.

Royo, C., J. Voltas and I. Romegosa (1999). Remobilization of pre-anthesis assimilates to the grain for grain only and DualPurpose triticale. Agron. J. 91:312-223.

Royo, C., M. Abaza, R. Blanco and L. F. Garcia (2000). Triticale gain growth and moyphometry as affected by drought stress, late sowing and simulated drought stress. Austr. J. Plant Physiol. 27:1051-5059.

Saxena, M. C., K. B. Singh and S. N. Silim (1989). Yield response to increase in moisture supply, pp. 225-229. Ann. Rep. ICARDA, Aleppo. Syria.

Saxena, K. B. and M. C. Saxena (1990). Studies on drought tolerance, pp. 108-113. Ann. Rep. ICARDA, Aleppo, Syria.

Simane, B. (1993). Ontogenetic analysis of yield components and yield stability of durum wheat in water limited environments. Euphytica 71:211-219. 